\title{
PENGARUH PEMBELAJARAN E-LEARNING TERHADAP HASIL BELAJAR MAHASISWA PGSD PADA MATA KULIAH KONSEP IPS LANJUT
}

\author{
Arif Mahya Fanny \\ Universitas PGRI Adi Buana Surabaya \\ Email: arifmahyafanny@gmail.com
}

\begin{abstract}
Abstrak
Penelitian ini bertujuan untuk mengetahui pengaruh penerapan pembelajaran e-learning terhadap hasil belajar pada mata kuliah Konsep IPS Lanjut. Metode yang digunakan dalam penelitian ini adalah eksperimen dengan pretest-posttest control group design. Instrument yang digunakan dalam penelitian ini adalah instrumen tes. Untuk mengetahui pengaruh penerapan pembelajaran e-learning terhadap hasil belajar maka data hasil tes belajar mahasiswa dianalisis dengan Uji-t. Berdasarkan hasil penelitian diperoleh nilai Sig.2 tailed (0.000) $<\alpha$ (0,05). Dengan demikian dapat disimpulkan bahwa terdapat pengaruh penerapan pembelajaran e-learning terhadap hasil belajar pada mata kuliah Konsep IPS Lanjut.
\end{abstract}

\section{Keywords: E-learning, Experiment, Hasil Belajar, Konsep IPS Lanjut}

\section{Pendahuluan}

Salah satu upaya mewujudkan sistem pembelajaran yang baik dan berkualitas maka dibutuhkan dosen atau guru yang profesional. Dalam hal ini adalah dosen atau guru yang berkompeten dalam bidangnya, yang mampu menghasilkan bibit-bibit penerus bangsa yang unggul, yang mampu mengikuti perkembangan jaman dan situasi sosial seperti sekarang. Namun faktanya yang ada saat ini masih ada pembelajaran yang dianggap belum berkualitas. Hal ini ditunjukkan dengan banyak mahasiswa yang masih kurang memiliki hasil belajar yang baik.

Nana Sudjana (2009) mendefinisikan hasil belajar siswa pada hakikatnya adalah perubahan tingkah laku sebagai hasil belajar dalam pengertian yang lebih luas mencakup bidang kognitif, afektif, dan psikomotorik. Dimyati dan Mudjiono (2006) juga menyebutkan hasil belajar merupakan hasil dari suatu interaksi tindak belajar dan tindak mengajar. Dengan demikian dapat disimpulkan bahwa hasil belajar adalah kemampuan-kemampuan yang dimiliki mahasiswa setelah menerima pengalaman belajarnya. Kemampuankemampuan tersebut mencakup aspek kognitif, afektif, dan psikomotorik. Hasil belajar dapat dilihat melalui kegiatan evaluasi yang bertujuan untuk mendapatkan data pembuktian yang akan menunjukkan tingkat kemampuan mahasiswa dalam mencapai tujuan pembelajaran.

Berdasarkan hasil identifikasi pada mata kuliah IPS Konsep IPS Lanjut hasil belajar mahasiswa rendah. Selain itu, kehadiran mahasiswa dari pertemuan pertama hingga pertemuan di akhir semester cenderung menurun. Pada pertemuan pertama seluruh mahasiswa hadir namun pada pertemuan setelah ujian tengah semester (UTS) hanya sebagian dari mahasiswa yang hadir. Kehadiran mahasiswa dapat mempengaruhi hasil belajar, sehingga mahasiswa harus mengikuti remidi di akhir semester. Oleh 
karena dibutuhkan proses pembelajaran yang lebih kreatif agar mahasiswa yang tidak dapat hadir dalam pertemuan di kelas dapat mengikuti perkuliahan dengan maksimal.

Sugihartono, dkk. (2007: 76-77), menyebutkan faktor-faktor yang mempengaruhi hasil belajar, yaitu faktor internal adalah faktor yang ada dalam diri individu yang sedang belajar meliputi: faktor jasmaniah dan faktor psikologis. Faktor eksternal adalah faktor yang ada di luar individu meliputi: faktor keluarga, faktor sekolah, dan faktor masyarakat.

Saat ini pendidikan memanfaatkan fasilitas teknologi informasi dari yang sederhana sampai kepada yang sangat canggih. Kemajuan ilmu pengetahuan dan teknologi, khususnya teknologi informasi banyak membawa dampak positif bagi kemajuan dunia pendidikan dewasa ini. Generasi yang ada di perguruan tinggi saat ini diasumsikan masuk ke dalam golongan net generation yang sangat terikat dengan teknologi informasi, khususnya teknologi berbasis web (Beyers, 2009).

Teknologi komputer dan internet, mulai dari perangkat lunak maupun perangkat keras memberikan banyak tawaran dan pilihan bagi dunia pendidikan untuk menunjang proses pembelajaran para mahasiswa. Keunggulan yang ditawarkan bukan saja terletak pada faktor kecepatan untuk mendapatkan informasi, namun juga fasilitas multimedia yang dapat membuat belajar lebih menarik melalui visual secara interaktif. Sejalan dengan perkembangan teknologi informasi, banyak kegiatan pembelajaran yang dapat dilakukan dengan memanfaatkan teknologi ini.

Pemanfaatan teknologi informasi terwujud dengan adanya e-learning. Electronic learning (e-learning) pada hakekatnya merupakan pendekatan belajar, atau pembelajaran melalui pemanfaatan pendekatan teknologi komputer dan internet. Dabbagh dan Bannan-Ritland (Prawiradilaga, 2014) menyatakan bahwa konsep e-learning menggunakan fasilitas jaringan global untuk menyampaikan materi ajar serta memanfaatkannya untuk menciptakan interaksi antara pengajar dan peserta didik.

Pembelajaran online akan meningkatkan interaksi dalam pembelajaran. Tugas perancang pembelajaran dan guru dalam pembelajaran online adalah memilih, menyesuaikan, dan menyempurnakan, melalui umpan balik, penilaian, dan refleksi, kegiatan pendidikan yang memaksimalkan kemampuan web (Anderson, 2008). Laboratorium pembelajaran virtual di lembaga pendidikan hendaknya diaktifkan dan memberikan perhatian yang lebih pada hubungan antara konsep dan perkembangan keterampilan berpikir peserta didik (Sayed, 2013).

Berbagai perkembangan teknologi informasi dan komunikasi menyediakan banyak sekali aplikasi learning management system (LMS) yang langsung dapat digunakan untuk menunjang pembelajaran. LMS berfungsi sebagai repository sentral untuk menangani semua jenis kebutuhan pendidikan. Area utama yang ditangani oleh penyebaran LMS adalah Perencanaan Kurikulum, Evaluasi Instan, Keterlibatan Pelajar dan Manajemen Konten (Kulshrestha \& Khant, 2013).

Beberapa perangkat lunak LMS yang dikembangkan antara lain Moodle, Quipper, Edmodo, Google Classroom dan lain-lain. Aplikasi yang digunakan dalam penelitian ini adalah Google Classroom. Google Classroom merupakan aplikasi LMS yang dikembangkan oleh Google yang dapat 
dimanfaatkan oleh dosen dalam pembelajaran. Dalam Google Classroom, dosen dapat memberikan tugas yang bisa ditentukan waktu pengumpulannya serta mengunggah materi perkuliahan. Mahasiswa juga bisa berbagi pemikiran atau ide lewat postingan pada Google Classroom atau di Facebook biasa dikatakan update status. Fitur yang ditawarkan adalah:

1) Dosen dapat membuat banyak kelas

2) Bisa meng-edit gambar profil dan nama.

3) Assignment yang dapat diposting dosen sebagai PR (pekerjaan rumah) / tugas.

4) Pengaturan jadwal event-event penting.

5) Satu mahasiswa dengan banyak dosen.

6) Bisa diakses melalui handphone.

Aplikasi tersebut menerapkan sistem belajar yang diklaim mampu memfasilitasi pembelajaran mahasiswa sehingga diharapkan mampu mempengaruhi hasil belajar mahasiswa PGSD pada Mata Kuliah Konsep IPS Lanjut.

\section{Metode Penelitian}

Lokasi penelitian dilaksanakan di Universitas PGRI Adi Buana Surabaya tepatnya di kampus II menanggal. Dengan objek penelitian mahasiswa program studi PGSD angkatan 2017 kelas A dan B.

Metode yang digunakan dalam penelitian ini adalah eksperimen dengan pretest-posttest control group design (Cresswell, 2005). Gambaran alur pelaksanaan penelitian pengaruh pembelajaran e-learning terhadap hasil belajar mahasiswa PGSD pada mata kuliah
Konsep IPS Lanjut dapat dilihat dalam

Tabel 1 sebagai berikut.

Tabel 1

Desain Penelitian

\begin{tabular}{cccc}
\hline Kelompok & $\begin{array}{c}\text { Pre- } \\
\text { test }\end{array}$ & $\begin{array}{c}\text { Pelaksanaan } \\
\text { Program }\end{array}$ & $\begin{array}{c}\text { Post- } \\
\text { test }\end{array}$ \\
\hline Eksperimen & $\mathrm{O}_{1}$ & $\mathrm{X}_{1}$ & $\mathrm{O}_{2}$ \\
\hline Kontrol & $\mathrm{O}_{1}$ & $\mathrm{X}_{2}$ & $\mathrm{O}_{2}$ \\
& & & \\
\hline
\end{tabular}

Tahapan yang dilakukan dalam penelitian ini adalah sebagai berikut:

a) Studi pendahuluan yang dilakukan melalui studi literature dan studi empiris. Studi literature dilakukan untuk mendapatkan dasar teori tentang hasil perkuliahan pada mata kuliah Konsep IPS Lanjut, sedangkan studi empiris dilaksanakan untuk mendapatkan gambaran hasil belajar melalui hasil belajar dan angket mahasiswa

b) Menyusun program hipotetik yang dirancang berdasarkan gambaran yang diperoleh dari studi pendahuluan yang telah dilakukan.

c) Revisi program yang dilakukan atas dasar validasi oleh pakar dan praktisi pengajar IPS sehingga diperoleh model akhir.

d) Pelaksanaan eksperimen yang dilakukan melalui beberapa tahapan sesuai dengan pemilihan desain yang telah dilakukan. Tahapan-tahapan yang dilakukan dalam eksperimen ini adalah sebagai berikut.

1) Mengadministrasi pretest yang dilakukan dengan pengamatan menggunakan pedoman observasi dengan bantuan observer.

2) Memberikan perlakuan eksperimen pada kelompok eksperimen. 
3) Memonitori proses sehingga ancaman terhadap validitas internal dapat diminimalisir.

4) Mengadministrasi post test yang dilakukan dengan pengamatan menggunakan pedoman observasi dengan bantuan observer.

e) Mengorganisasi dan menganalisis data aktivitas utama yang diperlukan dalam menyimpulkan eksperimen: pengkodean data, analisis data, dan penulisan hasil eksperimen.

f) Mengorganisasi dan menganalisis hasil belajar mahasiswa melalui pembelajaran e-learning.

Data hasil belajar mahasiswa dianalisis dengan menggunakan Uji-t. Sebelum dilakukan Uji-t sebelumnya dilakukan uji prasyarat analisis, yaitu uji normalitas dan uji homogenitas.

Uji normalitas dilakukan untuk melihat data berdistribusi normal atau tidak. Data berdistribusi normal jika nilai signifikan lebih dari 0,05. Sedangkan uji homogenitas dilakukan untuk melihat data berasal dari populasi yang memiliki varians sama atau tidak. Data homogen jika nilai signifikan lebih dari 0,05. Selanjutnya Uji-t dilakukan untuk melihat ada atau tidaknya perbedaan antara kelas kontrol dan eksperimen yang selanjutnya digunakan untuk menarik kesimpulan ada tidaknya pengaruh pembelajaran e-learning terhadap hasil belajar mahasiswa PGSD pada mata kuliah konsep IPS Lanjut. Ada tidaknya perbedaan jika nilai Sig. $\leq 0,05$. ( Julia Pallant, 2011). Dalam penelitian ini analisis data dilakukan dengan menggunakan software SPSS versi 19.

\section{Hasil dan Pembahasan}

Berdasarkan hasil

penelitian diperoleh bahwa kemampuan dosen dalam mengelola pembelajaran pada kelas eksperimen dengan menggunakan $e$ learrning dikategorikan sangat baik yang ditunjukkan dengan rata-rata presentase 91,6\%. Dari data tersebut menunjukkan bahwa fase pembelajaran e-learning sudah terlaksana dan dikategorikan baik sekali. Sedangkan kemampuan dosen dalam mengelola pembelajaran pada kelas kontrol yang tidak menggunakan pembelajaran $e$ learning dikategorikan cukup, hal ini terlihat dari rata-rata presentase $50 \%$.

Selanjutnya hasil belajar yang diperoleh berdasarkan penelitian menunjukkan bahwa pada saat pre-test ratarata nilai 76,3 pada kelas eksperimen dan kelas kontrol rata-rata nilai 76. Sedangkan pada saat post-test rata-rata nilai 84,3 untuk kelas eksperimen dan 75,6 untuk kelas kontrol. Hasil pretest dan postest mahasiswa disajikan dalam Gambar 1.

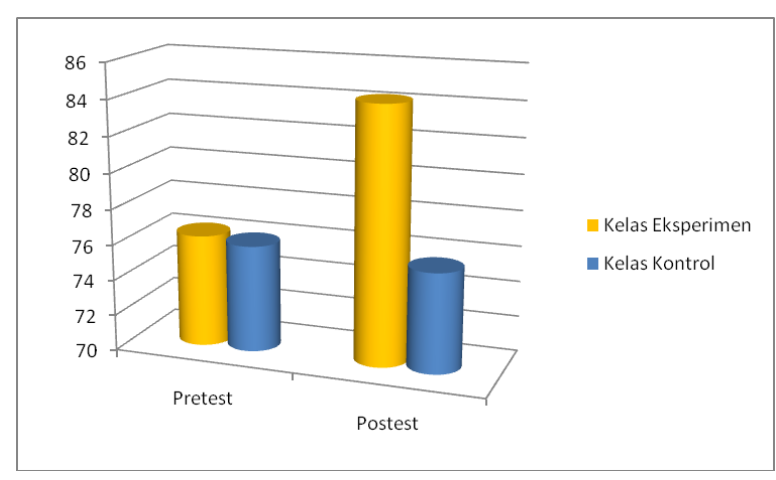

Gambar 1. Hasil pre-test dan Pos-test mahasiswa

Hasil uji homogenitas diperoleh nilai Sig $(0.002)<\alpha(0,05)$. Dari hasil tersebut dapat disimpulkan bahwa kedua kelas tersebut memiliki varian yang sama (Homogen). Hasil uji normalitas diperoleh nilai kelas ekperimen Sig 2-tailed (0.071) < $\alpha(0,05)$ dan nilai kelas kontrol Sig 2-tailed $(0.135)<\alpha(0,05)$. Maka dapat disimpulkan 
bahwa kedua kelas tersebut berdistribusi normal.

Selanjutnya hasil uji-t diperoleh nilai Sig. 2 tailed $(0.000)<\alpha(0,05)$, maka dapat disimpulkan bahwa terdapat perbedaan hasil belajar antara kelas dengan menerapkan pembelajaran e-learning dengan kelas yang tidak menggunakan $e$ learning.

Berdasarkan hasil analisis maka dapat dinyatakan bahwa penerapan e-learning memiliki pengaruh terhadap hasil belajar mahasiswa pada mata kuliah Konsep IPS Lanjut. Hasil ini sejalan dengan hasil penelitian yang dilakukan oleh Muharto, dkk (2016) dalam penelitiannya menemukan bahwa Kelompok e-learning lebih efektif hasil belajarnya daripada kelas tanpa e-learning. Oleh karena itu, perlu adanya penerapan model e-learning dalam pembelajaran.

Taslim, dkk (2017) dalam kajian penelitiannya menyatakan bahwa hasil belajar meningkat disebabkan oleh pelaksanaan e-learning. Kemudahan akses mahasiswa mempunyai pengaruh yang positif dan signifikan terhadap hasil belajar mahasiswa. Semakin mudah akses yang didapatkan mahasiswa dalam memanfaatkan e-learning, maka hasil belajar mahasiswa dapat meningkat.

\section{Kesimpulan}

Berdasarkan hasil penelitian dapat disimpulkan bahwa terdapat pengaruh berupa perbedaan hasil belajar antara kelas dengan menerapkan pembelajaran $e$ learning dengan kelas yang tidak menggunakan e-learning .

Penerapan pembelajaran dengan $e$ learning membutuhkan dukungan berupa fasilitas dan kebijakan yang dapat mendukung proses tersebut berjalan dengan baik. Hasil penelitian ini diharapkan dapat memberikan referensi bagi peneliti lain agar melaksanakan penelitian yang terkait selanjutnya.

\section{Daftar Acuan}

Anderson, T. 2008. The Theory and Practice of Online Learning: Second Edition. AU Press. Diakses pada 05 Agustus 2017 di: http://ufdcimages.uflib.ufl.edu/AA/00/ 01/17/00/00001/99Z

Anderson 2008-

Theory_and_Practice_of_Online_Lear ning.pdf

Beyers, R. N. . 2009. "A Five Dimensional Model for Educating the Net Generation". Educational Technology \& Society, 12 (4). Diakases pada 10 Maret 2019.

Creswell, J. 2005. Educational Research: Planning, Conducting, and Evaluating Quantitative and Qualitative Research. $2^{\text {nd }}$ Edition. New Jersey: Pearson Education Inc.

Kulshrestha, T., \& Kant, A. R., 2013. Benefits of Learning Management System (LMS) in Indian Education. International Journal of Computer Science \& Engineering Technology (IJCSET). Diakses pada 10 Maret 2019.

Muharto, Hasan, S., \& Ambarita, A. 2016. Penggunaan Model E-Learning Dalam Meningkatkan Hasil Belajar Mahasiswa Pada Materi Microprocessor. Indonesian Journal on Information System. Diakses pada 10 Maret 2018. 
Pallant, J. 2011. SPSS Survival Manual: $a$ step by step guide to data analysisusing SPSS. NSW: Allen\&Uwwin

Prawiladilaga, D.S. 2014. Wawasan Teknologi Pendidikan. Jakarta: Kencana.

Sayed, Mohamed. 2013. BlendedLearning Environments: The Effectiveness in Developing Concepts and Thinking Skills. Journal of Education and Practice. ISSN : 2222-1735 (Paper), ISSN : 2222-288X (Online) Vol.4,
No.25, 2013. Diakses pada 14 Februari 2017 di: http://iiste.org/Journals/index. php/JEP/article/viewFile/ 9034/9247.

Sudjana, Nana. 2009. Penilaian Hasil Proses Belajar Mengajar. Bandung: PT. Remaja Rosdakarya

Taslim, Toresa, D., \& Syahtriatna. 2017. Pengaruh Pengaplikasian E-learning Terhadap Hasil Belajar (Studi Kasus : Mahasiswa Keamanan Komputer Fasilkom Unilak). Jurnal Inovtek Polbeng. - Seri Informatika, Vol. 2, No. 2. Diakses tanggal 10 Maret 2019. 